\title{
Pengaruh Model Pembelajaran dan Kecerdasan Emosional terhadap Hasil Belajar Peserta Didik
}

\author{
Puji Laila Ramadhan \\ Pendidikan Kimia, Universitas Negeri Makassar \\ Email: pujilailaramadhan@gmail.com \\ Muhammad Anwar \\ Pendidikan Kimia, Universitas Negeri Makassar \\ Email: m_anwar66@yahoo.com \\ Sudding Sudding \\ Pendidikan Kimia, Universitas Negeri Makassar \\ Email: sudding.unm@gmail.com
}

(Diterima: 19-Desember-2019; direvisi: 20-Januari-2020; dipublikasikan: 19-Maret-2020)

\begin{abstract}
Abstrak: Penelitian ini bertujuan untuk mengetahui pengaruh model pembelajaran dan kecerdasan emosional terhadap hasil belajar peserta didik kelas XI SMA Negeri 12 Makassar. Metode penelitian ini menggunakan metode ekperimen semu (quasi ekperimental) yang digunakan adalah "factorial desain 3 x 3". Analisis data menggunakan uji normalitas, uji homogenitas, uji hpotesis dan untuk pengujian hipotesis dilakukan dengan one way ANOVA pada taraf signifikan 0,05 . Hasil analisis menunjukkan nilai rata-rata hasil belajar peserta didik kelas ekperimen 1 pada posttest yaitu 51,89, kelas eksperimen 2 yaitu 60,50 dan kelas eksperimen 3 yaitu 63,47. Persentase rata-rata nilai kategori kecerdasan emosional pada kategori rendah sebesar 59,6, berada pada kategori sedang sebesar 36,11 dan nilai kategori 55,14 berada dalam kategori tinggi. Hasil pengujian hipotesis 1 menggunakan analisis varians (anova) dengan program SPSS versi 22 for windows pada taraf signifikan, $\alpha=0,05$ diperoleh nilai signifikansi $(0,313>0,05)$, menunjukkan hipotesis ditolak. Disimpulkan bahwa tidak ada pengaruh model pembelajaran dan kecerdasan emosional terhadap hasil belajar peserta didik. Hasil pengujian hipotesis 2 pada taraf signifikan, $\alpha=0,05$ diperoleh nilai signifikansi $(0,997>0,05)$, menunjukkan hipotesis ditolak. Disimpulkan bahwa tidak ada pengaruh kecerdasan emosional terhadap hasil belajar peserta didik, hasil pengujian hipotesis 3 pada taraf signifikan, $\alpha=0,05$ diperoleh nilai signifikansi $(0,583>0,05)$, menunjukkan hipotesis ditolak. Disimpulkan bahwa tidak ada interaksi antara model pembelajaran dan kecerdasan emosional terhadap hasil belajar peserta didik kelas.
\end{abstract}

Kata kunci: Kecerdasan Emosional; Hasil Belajar; Hidrokarbon.

Abstract: This study aims to determine the effect of the influence of learning models and emotional intelligence on learning outcomes of XI grade students of SMA Negeri 12 Makassar. This research method uses quasi-experimental methods used is "factorial design 3 x 3". Data analysis using the normality test, homogeneity test, hpotesis test and for hypothesis testing is done by one way ANOVA at a significant level of 0.05. The results of the analysis show the average value of student learning outcomes in experimental class 1 in the posttest is 51.89, experimental class 2 is 60.50 and experimental class 3 is 63.47 . The average percentage of emotional intelligence in the low category is 59.6, in the moderate category is 36.11 and the value of the category 55.14 is in the high category. The results of testing the hypothesis 1 used analysis of variance (ANOVA) with the SPSS version 22 for 
windows program at a significant level, $\alpha=0.05$, obtained a significance value $(0.313>0.05)$, indicating the hypothesis was rejected. It was concluded that there was no influence of learning models and emotional intelligence on student learning outcomes. Hypothesis 2 test results at a significant level, $\alpha=0.05$ obtained significance value $(0.997>0.05)$, indicating the hypothesis was rejected. It was concluded that there was no influence of emotional intelligence on student learning outcomes. The results of testing the hypothesis 3 at a significant level, $\alpha=0.05$ obtained a significance value $(0.583>0.05)$, indicating the hypothesis was rejected. It was concluded that there was no interaction between learning models and emotional intelligence on learning outcomes of classroom students.

Keywords: Emotional Intelligence; Learning Outcomes; Hydrocarbons.

\section{PENDAHULUAN}

Guru telah melakukan berbagai upaya untuk meningkatkan kemampuan peserta didik tapi terkendala oleh motivasi peserta didik itu sendiri yang sulit untuk dibangun, hal ini juga didukung oleh model pembelajaran yang digunakan guru yang sebagian besar masih cenderung menggunakan model pembelajaran konvensional dengan metode ceramah sehingga kurang melibatkan peserta didik secara aktif dalam proses pembelajarannya dan mengakibatkan peserta didik memiliki hasil belajar rendah pada pembelajaran kimia.

Materi hidrokarbon merupakan materi yang membutuhkan pemahaman konsep lebih, apabila peserta didik kurang memahami konsep mereka akan kesulitan dalam belajar. Materi hidrokarbon mencakup rumus senyawa-senyawa serta reaksi-reaksi yang terjadi. Dalam materi ini juga banyak hal yang berkaitan dengan kehidupan sehari-hari. Oleh karena itu, dibutuhkan suatu model yang tepat agar peserta didik lebih aktif belajar dan tidak cepat merasa bosan. Maka perlu diupayakan suatu pembelajaran yang mampu mengaktifkan peserta didik dalam penyajian materi kimia yang menarik, sehingga dapat membantu peserta didik mengatasi kesulitan belajar dan menghilangkan persepsi buruk serta mindset awal mereka akan pelajaran kimia yang sulit.

Model PBL memberi peluang bagi peserta didik untuk mengasah kreativitas peserta didik dalam memecahkan suatu permasalahan yang berhubungan dengan konsep-konsep yang diajarkan. Dasar berpikir dari model pembelajaran ini adalah memberikan pengalaman langsung kepada peserta didik yaitu proses yang nyata, sesuai dengan prosedur dan menerapkan pemahaman yang dibentuk ke dalam pengalaman yang baru. Dalam proses pembelajaran peserta didik tidak hanya berperan sebagai penerima pelajaran melalui penjelasan guru saja tetapi peserta didik diberikan kesempatan untuk memecahkan masalah dan menemukan masalah baru sehingga peserta didik menjadi termotivasi dan mendapatkan hasil belajar yang lebih baik.

Model PBL merupakan suatu pendekatan pembelajaran dimana siswa mengerjakan permasalahan yang autentik dengan maksud untuk menyususn pengetahuan mereka sendiri, mengembangkan inkuiri dan keterampilan berpikir tingkat lebih tinggi, mengembangkan kemandirian dan kepercayaan diri (Arends dalam Trianto, 2009).

Adapun model pembelajaran lain seperti model pembelajaran inkuiri terbimbing yang dapat mendorong peserta didik berpikir dan bekerja atas inisiatif. Kebiasaan kegiatan ini dapat merangsang dan meningkatkan berpikir kritis pada peserta didik. Peserta didik dapat menemukan jawaban atas pertanyaan yang dirumuskan. Melalui pembelajaran inquiri terbimbing peserta didik terkondisi berpikir secara kritis dan kreatif untuk menemukan kesimpulan atas dasar observasi, pencarian jawaban yang dilakukan. Banyaknya 
kegiatan dalam model pembelajaran inkuiri terbimbing menunjukan besarnya keterlibatan aktifitas peserta didik dalam belajarnya. Banyaknya aktifitas belajar akan menghasilkan pengalaman belajar yang semakin banyak pula, yang merupakan hasil belajar peserta didik. Dengan demikian pembelajaran inkuiri terbimbing meningkatkan kemampuan intelektual, juga meningkatkan motivasi intrinsik dan ekstrinsik (Arends, 2004). Timbulnya motivasi intrinsik dan ekstrinsik akan menyebabkan meningkatnya gairah atau semangat serta kesadaran belajar peserta didik dan pada akhirnya akan meningkatkan hasil belajar kognitif (pemahaman konsep).

Inkuiri terbimbing dapat

didefenisikan sebagai dasar untuk mendapatkan pengetahuan tentang beberapa konsep kimia dengan memanfaatkan bimbingan agar pendidik mampu memisahkan tingkat tertentu dalam memecahkan masalah (Bilgin, 2009). Inkuiri terbimbing merupakan suatu cara yang efektif untuk membuat variasi suasana pola pembelajaran kelas. Penerapan model pembelajaran inkuiri terbimbing dapat meningkatkan antusias peserta didik dalam pelaksanaan kegiatan pembelajaran (Handayani, Sarwi, \& Praptiwi, 2012).

Penerapan model PBL maupun inkuiri terbimbing ini akan menambah variasi pembelajaran yang menarik, menyenangkan dan melibatkan peserta didik untuk aktif menemukan konsep sehingga akan meningkatkan aktivitas dan kerjasama peserta didik dalam kelompok. Membangun kepercayaan diri peserta didik sehingga akan lebih menyenangkan dan menarik peserta didik dalam belajar kimia khususnya dalam mempelajari hidrokarbon.

Hal lain yang mempengaruhi hasil belajar yaitu kecerdasan emosional, yaitu kemampuan untuk mengelola perasaannya, kemampuan untuk memotivasi dirinya sendiri, kesanggupan untuk tegar dalam menghadapi frustasi, kesanggupan mengendalikan dorongan dan menunda kepuasan sesaat, mengatur suasana hati yang relatif, serta mampu berempati dan bekerja sama dengan orang lain. Kemampuankemampuan ini mendukung peserta didik dalam mencapai tujuan dan cita-citanya (Trisnawati \& Suryaningsum, 2003).

Kemampuan akademik bawaan, nilai rapor, dan predikat kelulusan pendidikan tinggi tidak memprediksi seberapa baik kinerja seseorang sesudah bekerja atau seberapa tinggi sukses yang dicapai dalam hidup (McClelland dalam Goleman, 2003). Sebaliknya seperangkat kecakapan khusus seperti empati, disiplin diri, dan inisiatif mampu membedakan orang-orang sukses dari yang berprestasi biasa-biasa aja. Faktor ini dikenal sebagai kecerdasan emosional (EQ). EQ sendiri dapat diartikan sebagai kemampuan mengetahui perasaan sendiri dan perasaan orang lain, serta menggunakan perasaan tersebut menuntut pikiran dan perilaku seseorang (Salovey \& Mayer dalam Svyantek, 2003).

Kecerdasan emosional merupakan salah satu faktor penting yang harus dimiliki oleh peserta didik yang memiliki kebutuhan untuk meraih prestasi belajar yang lebih baik di sekolah. Dengan kecerdaan emosional, seseorang mampu mengetahui dan menanggapi perasaan mereka sendiri dengan baik dan mampu membaca serta menghadapi perasaan-perasaan orang lain dengan efektif. Berdasarkan uraian di atas maka peneliti tertarik untuk melakukan penelitian yang berjudul "Pengaruh Model Pembelajaran dan Kecerdasan Emosional terhadap Hasil Belajar Peserta Didik pada Materi Hidrokarbon".

\section{METODE}

Penelitian ini merupakan jenis penelitian eksperimen semu (quasi experimental). Desain penelitian yang digunakan yaitu desain factorial (factorial design) $3 \times 3$ karena menggunakan variabel bebas manipulatif yang dibagi tiga dan variabel atributif juga dibagi menjadi tiga kelompok. Penelitian ini telah dilaksanakan di SMAN 12 Makassar pada tanggal 15 Oktober 2019 di SMA Negeri 12 Makassar. Waktu penelitian dilaksanakan pada semester ganjil Tahun Ajaran 2018/2019. 
Populasi penelitian ini adalah semua peserta didik kelas XI MIA SMAN 12 Makassar semester ganjil tahun ajaran 2019/2020 dengan jumlah peserta didik 273 orang. Pengambilan sampel dilakukan dengan cara random sampling, dengan asumsi bahwa populasi bersifat homogen. Kelas yang terpilih akan di jadikan sebagai kelas eksperimen 1, 2, dan 3 yang dibelajarkan dengan menggunakan model PBL, konvensional dan inkuiri terbimbing.

Instrumen penelitian yang digunakan yaitu RPP dan LKPD untuk setiap kelas eksperimen. Selain, RPP dan LKPD digunakan juga instrument untuk mengukur kecerdasan emosional peserta didik yaitu tes kuesioner kecerdasan emosional dan tes hasil belajar. Sebelum digunakan, semua instrumen yang dibuat divalidasi oleh dua validator. Teknik analisis data yang digunakan dalam penelitian ini adalah statistik deskriptif dan statistik inferensial. Analisis statistik deskriptif digunakan untuk mendeskripsikan secara umum hasil belajar peserta didik. Kemudian hasilnya dianalisis menggunakan program aplikasi statistik SPSS versi 22 for windows. Analisis inferensial digunakan untuk mengukur hipotesis yang diajukan. Sebelum melakukan analisis statisik inferensial, dilakukan uji prasyarat analisis yang meliputi uji normalitas dan uji homogenitas data dengan SPSS 22 versi 22 for windows.

\section{HASIL DAN PEMBAHASAN}

Hasil penelitian yang disajikan terdiri dari deskripsi pengaruh model dan kecerdasan emosional terhadap hasil belajar peserta didik. Hasil analisis deskripsi hasil belajar peserta didik kelas XI IPA SMA Negeri Makassar ditinjau dari model pembelajaran untuk ketiga kelas setelah dibelajarkan dengan model pembelajaran PBL, inkuiri terbimbing dan konvensional dapat dilihat pada Tabel 1 .

Tabel 1. Deskripsi Hasil Belajar Peserta Didik dengan Model Pembelajaran

\begin{tabular}{cccc}
\hline \multirow{2}{*}{ Deskripsi } & \multicolumn{3}{c}{ Kelas dengan Model Pembelajaran } \\
\cline { 2 - 4 } & PBL & Inkuiri Terbimbing & Konvensional \\
\hline Jumlah sampel & 35 & 30 & 36 \\
Nilai tertinggi & 84 & 84 & 84 \\
Nilai terendah & 36 & 40 & 36 \\
Rata-rata & 56,11 & 63,33 & 60,5 \\
\hline
\end{tabular}

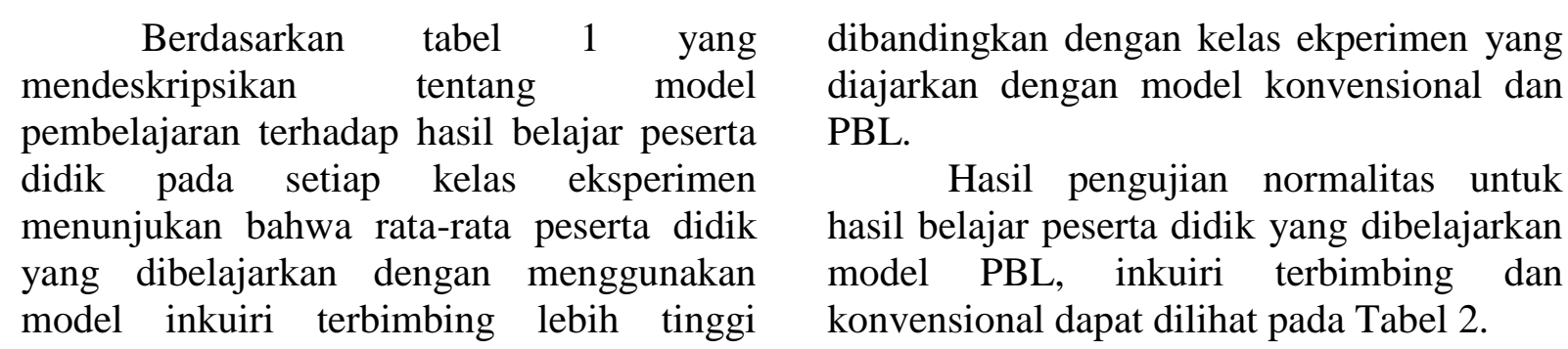

Tabel 2. Hasil Uji Normalitas Model Pembelajaran terhadap Hasil Belajar Peserta Didik Kelas XI IPA SMA Negeri 12 Makassar

\begin{tabular}{ccccc}
\hline \multirow{2}{*}{ Model Pembelajaran } & \multicolumn{3}{c}{ Kolmogorov-Smirnov $^{\text {a }}$} \\
\cline { 3 - 5 } & & Statistic & Df & Sig. \\
\hline \multirow{2}{*}{ Model } & PBL & 1,259 & 35 &, 084 \\
Pembelajaran & Inkuiri Terbimbing &, 870 & 30 &, 436 \\
& Konvensional & 1,093 & 36 &, 184 \\
\hline
\end{tabular}


Berdasarkan tabel 2 untuk kelas yang dibelajarkan dengan model PBL nilai signifikansi $0,085>\alpha 0,05$ dan kelas yang dibelajarkan dengan model inkuiri terbimbing nilai signifikansi $0,436>\alpha 0,05$ serta kelas yang dibelajarkan dengan konvensional nilai signifikansi $0,184>\alpha$ 0,05. Maka dapat disimpulkan bahwa hasil belajar peserta didik pada nodel PBL, inkuiri terbimbing dan konvensional adalah terdistribusi normal. Sedangkan untuk uji homogenitas didapatkan hasil pengujian homogenitas untuk hasil belajar peserta didik yang dibelajarkan model PBL, inkuiri terbimbing, dan konvensional dapat dilihat pada Tabel 3.

Tabel 3. Hasil Uji Homogenitas Model Pembelajaran terhadap Hasil Belajar Peserta Didik Kelas XI IPA SMA Negeri 12 Makassar

\begin{tabular}{cccc}
\hline Lavene Statistic & df1 & df2 & Sig. \\
\hline 1,267 & 8 & 92 &, 270 \\
\hline
\end{tabular}

Berdasarkan tabel 3 data homogenitas hasil belajar dengan model pembelajaran terhadap hasil belajar peserta didik menunjukkan nilai signifikasi $0,270>$ a 0,05 maka hasil belajar peserta didik dengan model pembelajaran terhadap hasil belajar peserta didik berasal dari populasi yang homogen. Setelah terpenuhinya uji prasyarat analisis variansi yang terdiri dari uji normalitas dan uji homogenitas varians, maka dilanjutkan dengan uji hipotesis. Hasil uji hipotesis untuk model pembelajaran terhadap hasil belajar peserta didik dapat dilihat pada Tabel 4.

Tabel 4. Hasil Pengujian Hipotesis Model Pembelajaran terhadap Hasil Belajar Peserta Didik Kelas XI IPA SMA Negeri 12 Makassar dengan Menggunakan Analisis Anava

\begin{tabular}{ccc}
\hline Sumber & Sig. & Keputusan \\
\hline Model Pembelajaran &, 313 & $\mathrm{H}_{0}$ diterima \\
\hline
\end{tabular}

Berdasarkan table 4 hasil analisis menunjukkan bahwa nilai sig, $0,313>\alpha=$ 0,05 berarti $\mathrm{H}_{0}$ diterima dan $\mathrm{H}_{1}$ ditolak artinya tidak terdapat pengaruh model PBL, inkuiri terbimbing dan konvensional terhadap hasil belajar peserta didik kelas XI IPA SMA Negeri 12 Makassar pada materi pokok hidrokarbon. Hasil analisis deskripsi kecerdasan emosional peserta didik kelas XI IPA SMA Negeri 12 Makassar ditinjau dari kecerdasan emosional untuk ketiga kelas setelah dibelajarkan dengan model pembelajaran PBL, inkuiri terbimbing, dan konvensional dapat dilihat pada Tabel 5.

Tabel 5. Deskripsi Kecerdasan Emosional terhadap Hasil Belajar Peserta Didik Kelas XI IPA SMA Negeri 12 Makassar

\begin{tabular}{cccc}
\hline \multirow{2}{*}{ Statistik } & \multicolumn{3}{c}{ Nilai Kecerdasan Emosioanal } \\
\cline { 2 - 4 } & PBL & Inkuiri Terbimbing & Konvensional \\
\hline N & 35 & 30 & 36 \\
Mean & 163,71 & 161,50 & 154,44 \\
Std. Deviation & 19,954 & 18,390 & 15,023 \\
Minimum & 117 & 94 & 120 \\
Maximum & 221 & 194 & 187 \\
\hline
\end{tabular}

Tabel 6. Deskripsi Kecerdasan Emosional Berdasarkan Kategori Kecerdasan Emosional (Sedang, Rendah, dan Tinggi) 


\begin{tabular}{cccc}
\hline \multirow{2}{*}{ Kecerdasan Emosional } & \multicolumn{3}{c}{ Hasil Belajar } \\
\cline { 2 - 4 } & PBL & Inkuiri Terbimbing & Konvensional \\
\hline Rendah & 59,42 & 60,8 & 60 \\
Sedang & 53,52 & 63,75 & 64,37 \\
Tinggi & 60,47 & 64 & 54,8 \\
\hline
\end{tabular}

Berdasarkan tabel 5 dan tabel 6 yang mendeskripsikan kecerdasan emosional peserta didik berdasarkan hasil belajar yang diajarkan dengan model pembelajaran terlihat bahwa nilai rata-rata hasil belajar peserta didik yang diajarkan dengan model inkuiri terbimbing memiliki kecerdasan emosional rendah lebih tinggi dibanding dengan nilai rata-rata hasil belajar pada model konvensional dan PBL. Sedangkan pada kecerdasan emosional sedang yang dibelajarkan dengan model konvensional memiliki rata-rata hasil belajar lebih tinggi dibandingkan dengan kelas yang diajarkan dengan model inkuiri terbimbing dan PBL. Dan kecerdasan emosional tinggi terlihat bahwa nilai rata-rata hasil belajar peserta didik diajarkan dengan model inkuiri terbimbing dibandingkan dengan PBL dan konvensional.

Hasil pengujian normalitas untuk kecerdasan emosional tinggi, sedang, dan rendah peserta didik kelas XI IPA SMAN 12 Makassar dapat dilihat pada Tabel 7.

Tabel 7. Hasil Uji Normalitas Kecerdasan Emosional Tinggi, Sedang, dan Rendah Peserta Didik Kelas XI IPA SMA Negeri 12 Makassar

\begin{tabular}{ccccc}
\hline \multirow{2}{*}{ Kecerdasan Emosional } & \multicolumn{3}{c}{ Kolmogorov-Smirnova $^{\mathbf{a}}$} \\
\cline { 3 - 5 } & & Statistic & Df & Sig. \\
\hline Tes Hasil & Rendah &, 183 & 22 &, 055 \\
Kecerdasan & Sedang &, 099 & 64 &, 189 \\
Emosional & Tinggi &, 184 & 15 &, 185 \\
\hline
\end{tabular}

Berdasarkan tabel 7 untuk kecerdasan emosional rendah nilai signifikansi 0,055 $>\alpha 0,05$ dan kecerdasan emosional sedang nilai signifikansi $0,189>$ a 0,05 serta kecerdasan emosional tinggi nilai signifikansi $0,185>\alpha 0,05$. Maka dapat disimpulkan bahwa kecerdasan emosional peserta didik pada kategori rendah, sedang, dan tinggi adalah terdistribusi normal. Sedangkan hasil pengujian homogenitas dengan rumus Levene's test of aqalty of error variance dengan bantuan program SPSS versi 22. Hasil pengujian homogenitas untuk kecerdasan emosional peserta didik dengan kategori rendah, sedang, dan tinggi dapat dilihat pada Tabel 8 .

Tabel 8. Hasil Uji Homogenitas untuk Kecerdasan Emosional Peserta Didik Kelas XI IPA SMA Negeri 12 Makassar

\begin{tabular}{c|c|c|c}
\hline Lavene Statistic & df1 & df2 & Sig. \\
\hline 1,267 & 8 & 92 &, 270 \\
\hline
\end{tabular}

Tabel 8 data homogenitas hasil belajar dengan model pembelajaran terhadap hasil belajar peserta didik menunjukkan nilai signifikasi $0,270>\alpha 0,05$ maka hasil belajar peserta didik dengan model pembelajaran terhadap hasil belajar peserta didik berasal dari populasi yang homogen.
Setelah terpenuhinya uji prasyarat analisis variansi yang terdiri dari uji normalitas dan uji homogenitas varians, maka dilanjutkan dengan uji hipotesis. Hasil uji hipotesis untuk kecerdasan emosional terhadap hasil belajar peserta didik dapat dilihat pada Tabel 9. 
Tabel 9. Hasil Pengujian Hipotesis Kecerdasan Emosional terhadap Hasil Belajar Peserta

Didik Kelas XI IPA SMA Negeri 12 Makassar dengan Menggunakan Analisis Anava

\begin{tabular}{cll}
\hline Sumber & Sig. & Keputusan \\
\hline Kecerdasan Emosional &, 997 & $\mathrm{H}_{0}$ diterima \\
\hline
\end{tabular}

Hasil analisis menunjukkan bahwa nilai sig, $0,997>\alpha=0,05$ berarti $\mathrm{H}_{0}$ diterima dan $\mathrm{H}_{1}$ ditolak artinya tidak terdapat pengaruh kecerdasan emosional terhadap hasil belajar peserta didik kelas XI IPA SMA Negeri 12 Makassar pada materi pokok hidrokarbon. Untuk hasil analisis deskripsi interaksi antara model pembelajaran dan kecerdasan emosional terhadap hasil belajar peserta didik kelas XI IPA SMA Negeri 12 Makassar dapat dilihat pada Tabel 10.

Tabel 10. Deskripsi Hasil Belajar Kimia Peserta Didik Berdasarkan Kategori Kecerdasan Emosional dan Model Pembelajaran

\begin{tabular}{ccccc}
\hline \multirow{2}{*}{ Model Pembelajaran } & Kecerdasan Emosional & Rendah & Sedang & Tinggi \\
\hline \multirow{3}{*}{ PBL } & Jumlah Sampel & 7 & 21 & 7 \\
& Nilai Tertinggi & 76 & 80 & 84 \\
& Nilai Terendah & 44 & 36 & 40 \\
& Rata-Rata & 59,42 & 53,52 & 60,47 \\
\hline \multirow{4}{*}{ Inkuiri Terbimbing } & Jumlah Sampel & 5 & 16 & 9 \\
& Nilai Tertinggi & 80 & 84 & 84 \\
& Nilai Terendah & 52 & 44 & 52 \\
& Rata-Rata & 60,8 & 63,75 & 64 \\
\hline \multirow{3}{*}{ Konvensional } & Jumlah Sampel & 10 & 16 & 10 \\
& Nilai Tertinggi & 84 & 80 & 80 \\
& Nilai Terendah & 44 & 44 & 36 \\
& Rata-Rata & 60 & 64,37 & 54,8 \\
\hline
\end{tabular}

Setelah terpenuhinya uji prasyarat analisis variansi yang terdiri dari uji normalitas dan uji homogenitas varians, maka dilanjutkan dengan uji hipotesis. Hasil pengujian hipotesis merupakan jawaban dari rumusan masalah yang telah dibuat dan pengujian hipotesis dengan menggunakan analisis anova. Hasil uji hipotesis untuk model pembelajaran dan kecerdasan emosional terhadap hasil belajar peserta didik kelas XI IPA SMA Negeri 12 Makassar dapat dilihat pada Tabel 11.

Tabel 11. Hasil Pengujian Hipotesis dengan Menggunakan Analisis Anava

\begin{tabular}{cll}
\hline Sumber & Sig. & Keputusan \\
\hline Model Pembelajaran*Kecerdasan Emosional &, 162 & $\mathrm{H}_{0}$ diterima \\
\hline
\end{tabular}

Hasil analisis menunjukkan bahwa nilai sig $0,162>\alpha=0,05$ berarti $\mathrm{H}_{0}$ diterima dan $\mathrm{H}_{1}$ ditolak artinya tidak terdapat interaksi model pembelajaran dan kecerdasan emosional terhadap hasil belajar peserta didik kelas XI IPA SMA Negeri 12 Makassar pada materi pokok hidrokarbon.
1. Pengaruh Model Pembelajaran terhadap Hasil Belajar Peserta Didik Kelas XI IPA SMA Negeri 12 Makassar pada Materi Pokok Hidrokarbon

Berdasarkan hasil analisis statistik deskripsi diperoleh model pembelajaran terhadap hasil belajar peserta didik pada 
setiap kelas eksperimen menunjukan bahwa rata-rata peserta didik yang dibelajarkan dengan menggunakan model inkuiri terbimbing lebih tinggi dibandingkan dengan kelas ekperimen yang diajarkan dengan model konvensional dan PBL.

Hasil analisis inferensial diperoleh nilai signifikansi $0,313>\alpha=0,05$. Sehingga dapat disimpulkan tidak terdapat perbedaan hasil belajar peserta didik kelas XI IPA SMA Negeri 12 Makassar yang dibelajarkan dengan model PBL, inkuiri terbimbing dan konvensional pada materi hidrokarbon. Tidak adanya perbedaan hasil belajar peserta didik berarti tidak ada pengaruh model pembelajaran terhadap hasil belajar peserta didik.

Hasil analisis data penelitian tentang hasil belajar peserta didik pada setiap kelas ekperimen menunjukkan bahwa hasil belajar peserta didik yang dibelajarkan dengan model inkuiri terbimbing lebih tinggi dibandingkan dengan nilai peserta didik yang dibelajarkan dengan menggunakan model konvensional dan PBL. Berdasarkan hasil belajar, rata-rata nilai hasil belajar peserta didik yang dibelajarkan menggunakan model inkuiri terbimbing memiliki nilai rata-rata lebih tinggi dibandingkan nilai rata-rata hasil belajar peserta didik yang diajarkan dengan konvensional dan PBL.

Model inkuiri terbimbing mampu memperbaiki dan meningkatkan keterampilan-keterampilan dalam proses belajar peserta didik misalnya usaha inkuiri terbimbing yang dilakukan tergantung pada bagaimana cara belajar peserta didik tersebut. Hal ini merupakan suatu kesenangan tersendiri karena dengan model inkuiri terbimbing peserta didik berhasil dan percaya diri dalam menemukan suatu konsep karena mampu bekerja sama dengan yang lainnya dalam satu kelompok. Model ini mampu membuat peserta didik berkembang dengan menemukan sendiri informasi dan konsep-konsep baru serta melakukan penyelidikan terhadap suatu masalah dan dapat memperoleh pengetahuan yang lebih bermakna.
Sedangkan penerapan dengan model PBL peserta didik terlihat kurang terampil dalam memecahkan masalah dengan permasalahan nyata yang diberikan oleh guru baik berkelompok maupun individu. Menurut Gagne (1989) belajar adalah suatu proses dimana suatu organisasi berubah perilakunya. Belajar terdiri dari tiga komponen penting, yaitu kondisi eksternal, kondisi internal, dan hasil belajar. Hasil belajar termasuk prestasi belajar dalam aspek pengetahuan, ditentukan dari interaksi kondisi internal dan eksternal peserta didik. Pada proses diskusi terlihat hanya beberapa orang saja dalam kelompok yang lebih dominan dan aktif dalam menyelesaikan masalah, yang lain hanya menginginkan hasil akhir tanpa mengikuti diskusi, hal ini yang terlihat dari proses pembelajaran.

Pernyataan tersebut menunjukkan bahwa model pembelajaran (kondisi eksternal) bukan satu-satunya penentu prestasi pengetahuan. Faktor internal peserta didik seperti gaya belajar, logika berpikir kemampuan verbal, kemampuan numerik, kemampuan analisis, kemampuan memori juga memberikan sumbangan terhadap prestasi belajar. Teori belajar konstruktivisme beranggapan bahwa ilmu pengetahuan bukanlah suatu fakta yang tinggal ditemukan, melainkan suatu hal perumusan yang diciptakan orang yang hendak mempelajarinya.

Kendala lain yang ditemui saat pembelajaran dengan model PBL adalah saat pertemuan pertama suasana kelas kurang kondusif dikarenakan peserta didik belum terbiasa dengan model pembelajaran tersebut, sehingga peserta didik kesulitan mengikuti pembelajaran. Namun setelah pertemuan kedua dan selanjutnya, peserta didik sudah mulai beradaptasi dengan model PBL yang diterapkan dikelas. Kelompok yang awalnya tertinggal sudah mulai bisa bersaing dengan kelompok lainnya, sehingga pembelajaran dikelas lebih aktif. Meski demikian, masih ditemukan pula kendala seperti manajemen waktu yang kurang efektif. Penyebab lain yang membuat pembelajaran kurang efektif dan kurang 
kondusif adalah pesserta didik yang tidak disiplin. Beberapa peserta didik tidak mengikuti aturan dengan baik seperti terlambat masuk kelas, mengajak teman kelompok lain berbicara saat diskusi berlangsung, serta keluar kelas dalam waktu yang cukup lama. Oleh karena alasan tersebut, maka target efektif yang sudah ditetapkan tidak tercapai.

Sementara pembelajaran dengan model konvensional memiliki nilai rata-rata hasil belajar cukup baik dibandingkan dengan model PBL. Hal ini sebabkan oleh pengaruh model dalam mengelola dan mengontrol kelas cukup baik sehingga peserta didik dapat mengetahui sampai sejauh mana menguasai materi yang disampaikan. Model konvensional ternyata dapat memberikan suasana yang menyenangkan sehingga peserta didik tidak merasa jenuh dan bosan.

Kesulitan peserta didik terhadap pelajaran kimia dapat disebabkan oleh dua faktor, yaitu faktor internal yang berasal dari dalam diri peserta didik dan faktor eksternal yang berasal dari luar diri peserta didik. Faktor internal ini dipengaruhi oleh tiga faktor yaitu faktor jasmani, faktor psikologis dan faktor kelelahan, sedangkan faktor eksternal yang mempengaruhi peserta didik dalam kegiatan belajar adalah faktor keluarga, faktor sekolah dan faktor masyarakat (Slameto, 2003). Faktor internal, terutama faktor kelelahan sangat mempengaruhi selama proses belajar mengajar, karena sekolah menerapkan full day school. Dan penempatan jam belajar kimia ditempatkan pada jam-jam istrahat, yaitu jam 13.10-15.30 sebelum proses pembelajaran dimulai peserta didik sudah loyo, mengantuk dan kehilangan semangat belajar, sehingga mempengaruhi hasil belajar peserta didik kelas XI IPA SMA Negeri 12 Makassar materi pokok hidrokarbon.

Penelitian beberapa ahli learning style (gaya belajar), prestasi belajar tidak bergantung pada waktu secara mutlak, tetapi tergantung pada pilihan waktu yang cocok dengan kesiapsiagaan peserta didik
(Muhibbin, 2008), dengan demikian, waktu yang digunakan peserta didik untuk belajar yang selama ini dipercaya berpengaruh terhadap hasil belajar peserta didik, karena bukan masalah waktu yang penting dalam belajar, melainkan kesiapan sistem memori peserta didik dalam menyerap, mengelola, dan menyimpan informasi atau pengetahuan yang dipelajari peserta didik tersebut. Tetapi menurut sebagian besar peserta didik kelas XI IPA 1, XI IPA 2, dan XI IPA 3, mereka lebih menyenangi pelajaran kimia dilaksanakan pada pagi hari (07.15-12.00) dengan alasan keadaan bada masih segar, tidak mengantuk, sehingga mudah menyerap materi. Sehingga diperoleh nilai rata-rata hasil belajar peserta didik setiap model pembelajaran, PBL dengan nilai rata-rata 56,11 , inkuiri terbimbing dengan nilai ratarata 63,33 dan konvensional dengan nilai rata-rata 60,5 .

Adapun kendala atau kelemahan dari model PBL, inkuiri terbimbing dan konvensional yaitu keterbatasan waktu, sedangkan model pembelajaran ini memerlukan waktu yang banyak, sehingga diharapkan guru dalam melaksanakan proses belajar mengajar dapat merencanakan dan mengolah alokasi waktu dengan baik dan benar. Hal ini juga dapat diatasi melalui kegiatan pembelajaran yang melibatkan media penyampaian materi seperti LKPD dan menyuruh peserta didik untuk mencari dan mempelajari materi selanjutnya sehingga waktu yang diperlukan dalam proses belajar pembelajaran tidak terlalu lama.

\section{Pengaruh Kecerdasan Emosional terhadap Hasil Belajar Kimia Peserta Didik Kelas XI IPA SMA Negeri 12 Makassar pada Materi Pokok Hidrokarbon}

Berdasarkan penelitian yang telah dilakukan, secara keseluruhan rata-rata nilai kecerdasan emosional peserta didik yang memiliki kecerdasan emosional rendah, sedang dan tinggi berbeda sehingga kecerdasan emosional secara signifikan tidak mempengaruhi hasil belajar peserta didik. Hal ini terjadi karena pada proses 
pelaksanaannya materi disampaikan kepada peserta didik dengan memperhatikan ketiga kategori kecerdasan emosional tersebut, sehingga mendeskripsikan hasil belajar peserta didik berdasarkan model pembelajaran dan kategori kecerdasan emosional peserta didik terlihat bahwa kecerdasan emosional rendah, nilai rata-rata 60. Kecerdasan emosional sedang, nilai ratarata 59,88 dan kecerdasan emosional tinggi, nilai rata-rata 59,53.

Hasil analisis menunjukkan bahwa nilai sig, $0,997>\alpha=0,05$ berarti $\mathrm{H}_{0}$ diterima dan $\mathrm{H}_{1}$ ditolak artinya tidak terdapat pengaruh kecerdasan emosional terhadap hasil belajar peserta didik kelas XI IPA SMA Negeri 12 Makassar pada materi pokok hidrokarbon. Sesuai dengan penelitian Austin, Wendy, \& Boyd (2010) menyimpulkan bahwa mahasiswa dengan tingkat kecerdasan emosional tinggi tidak mudah mengalami stress dari pada mahasiswa dengan tingkat kecerdasan emosional rendah saat mahasiswa menjelang ujian. Selain itu, Thaib (2013) menunjukkan bahwa kecerdasan emosional dapat dinyatakan sebgai salah satu faktor penting yang seharus dimiliki oleh peserta didik sebagai kebutuhan untuk meraih prestasi belajar yang lebih baik di sekolah serta menyiapkan mereka menghadapi dunia nyata.

Penelitian di atas menunjukkan bahwa faktor yang mempengaruhi hasil belajar yaitu tingkat kecerdasan emosional diri peserta didik itu sendiri, jika peserta didik mampu mengendalikan emosinya pada situasi apapun terutama saat pembelajaran maka ia tidak mudah mengalami stress dan lebih siap menghadapi ujian. Namun pada penelitian ini tidak terdapat pengaruh tingkat kecerdasan emosional peserta didik terhadap hasil belajar peserta didik kelas XI IPA SMA Negeri 12 Makassar pada materi pokok hidrokarbon.

Penelitian ini menunjukkan bahwa kecerdasan emosional tidak memberikan pengaruh untuk hasil belajar peserta didik. Ini membuktikan bahwa peserta didik memiliki perbedaan tingkat pertanyaan emosional. Namun, tidak dapat dipungkiri bahwa kecerdasan emosi adalah sumber belajar yang penting mencapai tidak hanya keberhasilan belajar tetapi juga kesuksesan hidup. Dalam hal ini, kesuksesan mencakup segala hal yang berkaitan dengan pembelajaran hasil di mana peserta didik dituntut untuk terlibat aktif dalam setiap proses pembelajaran, sehingga peserta didik tidak akan memahami materi dengan lebih mudah tetapi juga akan dapat menjawab pertanyaan yang diberikan.

Data menunjukkan bahwa rata-rata hasil belajar peserta didik yang diajarkan dengan model PBL dengan kecerdasan emosional secara signifikan tidak mempengaruhi hasil belajar peserta didik dan hasil belajar peserta didik dengan kecerdasan emosioan tinggi yang diperoleh adalah $84 \pm 40$. Hasil belajar peserta didik yang diajarkan dengan model PBL kecerdasan emosional sedang dengan skor tertinggi $80 \pm 36$ dan hasil belajar peserta didik yang diajarkan dengan model PBL kecerdasan emosional rendah dengan skor tertinggi $76 \pm 44$. Sedangkan, hasil belajar peserta didik yang diajarkan dengan model inkuiri terbimbing dengan kecerdasan emosional rendah adalah $80 \pm 52$, dan hasil belajar peserta didik yang diajarkan dengan menggunakan model inkuiri terbimbing dengan kecerdasan emosional sedang adalah $84 \pm 44$. Hasil belajar peserta didik yang diajarkan dengan model inkuiri terbimbing dengan kecerdasan emosional tinggi adalah $84 \pm 52$. Dan untuk model konvensional hasil belajar peserta didik yang diajarkan dengan model konvensional dengan kecerdasan emosional rendah adalah $84 \pm 44$, dan hasil belajar peserta didik yang diajarkan dengan menggunakan model konvensional dengan kecerdasan emosional sedang adalah $80 \pm 44$. Dan hasil belajar peserta didik yang diajarkan dengan model konvensional dengan kecerdasan emosional tinggi adalah $80 \pm 36$.

Ditemukan bahwa hasil belajar peserta didik dengan kecerdasan emosial dengan kategori tinggi yang diajarkan dengan menggunakan model PBL dan 
inkuiri terbimbing memiliki rata-rata hasil belajar yang lebih baik daripada peserta didik yang diajarkan dengan menggunakan model konvensional. Selain itu, pada kelas dengan model PBL dan inkuiri terbimbing dengan kecerdasan emosional tinggi menemukan bahwa peserta didik dengan kecerdasan emosional tinggi akan dengan mudah mendapatkan hasil belajar yang lebih baik dibandingkan dengan menggunakan model konvensional. Hal ini di karenakan penerapan model PBL dan inkuiri terbimbing dalam pembelajaran kimia menuntut peserta didik untuk bekerja sama dalam menemukan suatu konsep dan prinsip dan mampu bekerja sama dengan yang lainnya dalam satu kelompok dan dalam proses pembelajarannya peserta didik diberikan kesempatan untuk menjelaskan materi dengan caranya sendiri sampai teman satu kelompoknya mengerti dengan apa yang dijelaskan.

Peserta didik dengan kecerdasan emosionnal tinggi membutuhkan komunikasi untuk bekerja dengan orang lain dalam diskusi kelompok, sehingga peserta didik mampu mengemukakan dan menjelaskan gagasan-gagasan baru dan peserta didik lebih senang dan nyaman dalam menyelesaikan proses pembelajaran. Untuk terlibat dengan orang lain, para peserta didik diminta untuk bertanggung jawab dengan tugas mereka sendiri. Sedangkan, peserta didik kecerdasan emosinal rendah dengan yang diajarkan dengan menggunakan model PBL, inkuiri terbimbing menunjukkan bahwa peserta didik dengan kecerdasan emosional rendah tampak agak sulit untuk berbaur dengan peserta didik yang lain dalam diskusi kelompok. peserta didik sulit mempercayai orang lain, mereka lebih cenderung kurang peduli.

Terkait dengan fakta ini, peserta didik dengan kecerdasan emosi rendah mengalami kesulitan untuk mendapatkan hasil belajar yang baik jika guru kurang tepat dalam memilih model pembelajaran. Untuk alasan tersebut, dapat di sarankan untuk peserta didik dengan kecerdasan emosional tinggi akan lebih efektif, jika peserta didik diajarkan dengan model PBL dan inkuiri terbimbing sedangkan peserta didik dengan kecerdasan emosional rendah dan sedang lebih efektif diajarkan dengan model konvensional.

\section{Pengaruh Interaksi Model Pembelajaran terhadap Hasil Belajar Kimia Peserta Didik Kelas XI IPA SMA Negeri 12 Makassar pada Materi Pokok Hirokarbon}

Berdasarkan hasil analisis statistik diperoleh menunjukkan bahwa hasil belajar peserta didik yang memiliki hasil belajar tinggi dengan peserta didik yang memiliki kecerdasan emosional sedang nilai signifikan diperoleh $0,583>\alpha=0,05$ berarti $\mathrm{H}_{0}$ diterima dan $\mathrm{H}_{1}$ ditolak artinya tidak ada interaksi antara model pembelajaran dan kecerdasan emosional dalam mempengaruhi hasil belajar peserta didik kelas XI IPA SMA Negeri 12 Makassar pada materi hidrokarbon.

Hasil belajar yang memiliki kecerdasan emosional tinggi berbeda secara signifikan dengan hasil belajar peserta didik yang memiliki kecerdasan emosional rendah. Dapat disimpulkan bahwa peserta didik yang memiliki kecerdasan emosional redang, sedang, dan tinggi secara signifikan tidak berpengaruh terhadap hasil belajar peserta didik kelas XI IPA SMA Negeri 12 Makassar pada materi hidrokarbon.

Hasil analisis statistik deskripsi menunjukkan bahwa hasil belajar peserta didik berdasarkan model pembelajaran dan kategori kecerdasan emosional peserta didik. Kecerdasan emosional rendah, nilai rata-rata 60, kecerdasan emosional sedang, nilai ratarata 59,88 dan kecerdasan emosional tinggi, nilai rata-rata 59,53. Nilai rata-rata hasil belajar peserta didik pada kelas yang dibelajarkan dengan menggunakan model pembelajaran inkuiri terbimbing $(63,33)$ lebih tinggi dibandingkan dengan kelas yang dibelajarkan dengan model PBL $(56,11)$ dan model konvensional $(60,5)$.

Dari data tersebut terlihat bahwa hasil belajar peserta didik yang diajarkan dengan model inkuiri terbimbing 
mendapatkan hasil yang paling baik dari model pembelajaran PBL dan konvensional. Terdapat perbedaan yang tidak signifikan hasil belajar peserta didik yang diajarkan dengan model PBL, inkuiri terbimbing dan konvensional pada kelas XI IPA SMA Negeri 12 Makassar maka dapat disimpulkan bahwa model pembelajaran tidak berpengaruh terhadap hasil belajar peserta didik.

Peserta didik dengan model pembelajaran konvensional dengan kecerdasan emosional sedang memiliki hasil belajar yang lebih baik dibandingkan peserta didik dengan kecerdasan emosional tinggi. Hal tersebut seperti perbedaan emosional dan kognitif atau hal-hal yang dinilai mampu mengganggu keefektifan proses belajar peserta didik (Thomas, 2009 dan Baum, Julie, \& Barbara, 2005) keefektifan yang rendah dan disebabkan oleh faktorfaktor yang dijelaskan akan membutuhkan waktu yang lebih bagi pendidik agar mengarahkan dan mengingatkan mereka. Proses ini akan memahamkan peserta didik untuk berhenti berfikir ke hal-hal yang merugikan dan mempengarui sikap/perilaku mereka dalam belajar. Teori menunjukkan bahwa pendidik perlu untuk mengidentifikasi level kecerdasan emosional dengan mengkaji berbagai pendekatan yang dirasakan cocok untuk diimplementasikan terhadap berbagai jenis peserta didik. Sehingga dapat disimpulkan bahwa jika dalam suatu kelas dominan dengan kecerdasan emosional tinggi dan sedang sebaiknya menggunakan model pembelajaran inkuiri terbimbing dan PBL. Sedangkan jika peserta didik dengan kecerdasan emosional rendah dan sedang sebaiknya menggunakan model pembelajaran konvensional. Interaksi model pembelajaran dan kecerdasan emosional dapat dilihat pada Gambar 1.

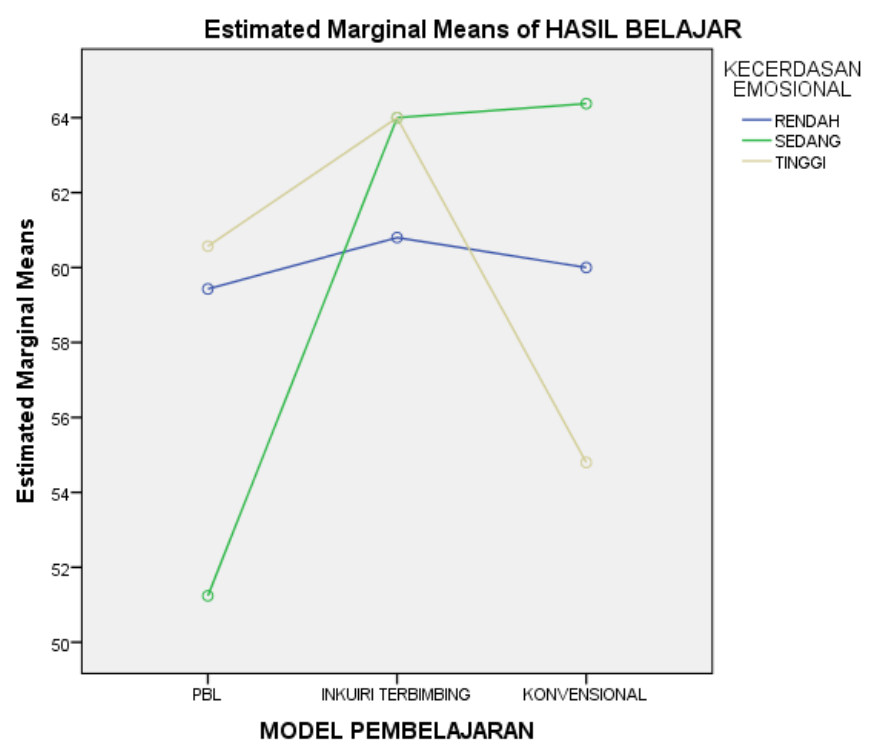

Gambar 1. Grafik Interaksi Model Pembelajaran dan Kecerdasan Emosional terhadap Hasil Belajar Peserta Didik Kelas XI IPA SMA Negeri 12 Makassar pada Materi Pokok Hidrokarbon

Berdasarkan gambar interaksi antara model pembelajaran dan kecerdasan emosional menunjukkan bahwa terdapat perbedaan antara selisih hasil belajar kimia peserta didik dengan kecerdasan emosional rendah, sedang dan tinggi yang diajarkan dengan model PBL, inkuiri terbimbing dan konvensional di kelas XI IPA SMA Negeri 12 Makassar. Pada gambar dapat dijelaskan bahwa peserta didik yang diajarkan dengan model pembelajaran inkuiri terbimbing dengan kecerdasan emosional tinggi 
memiliki kecerdasan emosional lebih baik dibandingkan dengan kecerdasan emosional sedang dan rendah. Hal ini sama halnya pada kelas yang diajarkan dengan model pembelajaran PBL dimana peserta didik dengan kecerdasan emosional sedang memiliki hasil belajar kimia yang baik.

Hasil analisis deskriptif dan inferensial serta grafik interaksi menunjukkan bahwa tidak terdapat pengaruh interaksi antara model pembelajaran dan kecerdasan emosional terhadap hasil belajar peserta didik kelas XI IPA SMA Negeri 12 Makassar pada materi pokok hirokarbon.

\section{SIMPULAN DAN SARAN}

Berdasarkan hasil penelitian dan pembahasan, maka dapat disimpulkan bahwa tidak ada pengaruh model pembelajaran terhadap hasil belajar peserta didik kelas XI IPA SMA Negeri 12 Makassar pada materi hidrokarbon. Kecerdasan emosional tidak memberikan efek besar pada hasil belajar peserta didik pada materi hidrokarbon. Sementara, model pembelajaran PBL, inkuiri terbimbing dan konvensional tidak berpengaruh signifikan terhadap hasil belajar peserta didik. Namun, jika peserta didik memiliki kecerdasan emosional tinggi, lebih baik diajarkan dengan model PBL dan Inkuiri terbimmbing. Jika peserta didik memiliki kecerdasan emosional sedang dan rendah lebih baik dianjurkan dengan model konvensional. Tidak ada interaksi antara model pembelajaran dan kecerdasan emosional terhadap hasil belajar peserta didik kelas XI IPA SMA Negeri 12 Makassar pada materi hidrokarbon.

\section{DAFTAR RUJUKAN}

Arends. 2004. Belajar dan Pembelajaran. Jakarta: Rineka Cipta.

Arends, dalam Trianto. 2009:25,81. Mendesain Model Pembelajaran Inovatif-Progresif. Jakarta: Kencana Prenada Group.

Austin, Wendy, \& Boyd, M. A. 2010. Psychiatric and Mental Health
Nursing Faor Canadian Practice. London: Whurr Publishers.

Baum, S., Julie, V., \& Barbara, S. 2005. Multiple Intellengences in The Classroom. Columbia University. New York: Teacher College Press.

Bilgin, I. 2009. The Effect of Guided Inquiry Instruction Incorporating a Cooperative Learning Approach on University Students' Achievement of Acid and Based Concepts and Attitude Toward Guided Inquiry Instruction. Scientific Research and Essay, 4(10), 1038-1046.

Gagne, R. M. 1989. Kondisi Belajar dan Teori Pembelajaran. Jakarta: PAU Dirjen Dikti Depdikbud.

Goleman, D. 2003. Emotional Intelligence. Jakarta: PT. Gramedia Pustaka Utama.

Handayani, Sarwi, L., \& Praptiwi. 2012. Efektivitas Model Pembelajaran Eksperimen Inkuiri Terbimbing Berbantuan My Own Dictionary untuk Meningkatkan Penguasaan Konsep dan untuk Kerja Siswa SMP RSBI. Unnes Science Education Journal, 1(2), 117-129.

Muhibbin, S. 2008. Psikologi Pendidikan. Bandung: Remaja Rosdakarya.

Slameto. 2003. Belajar dan Factor-Faktor yang Mempengaruhinya. Jakarta: Rineka Cipta.

Svyantek, D. J. 2003. Emotional Entellegence and Organizational behavior-II. The Internasional Journal of Organization Analysis, 11(3), 167-169.

Thaib, E. N. 2013. Hubungan Antara Prestasi Belajar dengan Kecerdasan Emosional. Jurnal Ilmiah Didaktika, 13(2), 384-399.

Thomas, A. 2009. Multiple Intelegences in The Classroom. CA: Cloverdale.

Trisnawati, E. I., \& Suryaningsum, S. 2003. Pengaruh Kecerdasan Emosional terhadap Tingkat Pemahaman Akuntansi. Simposium Nasional Akuntansi (SNA) VI, Surabaya, 1073-1091. 